\title{
Influence of Internet-based Information Technology in the Information Literacy in Higher Educational Institutions
}

Zheng Xu

Zhumadian Vocational And Technical College, Zhumadian City

Zip Code: 463000, Henan Province

China

ABSTRACT: The higher education sector has witnessed tremendous changes due to the rapid rise and use of Internet based information technology in the last few years. It naturally has good impact in the higher education and particularly on the information technology based literacy teachers training. Many institutions face challenges in the light of the above and many have experienced high amount of manpower and resources loss. The current work is intended to analyse the current position of information literacy in the higher education sector, and discussed the methods for effective exploitation of information literacy.

Keywords: Education Teaching Mode, Teachers’ Information Literacy, The Status Quo, Method

Received: 2 April March 2019, Revised 15 June 2019, Accepted 28 June 2019

DOI: $10.6025 / \mathrm{jjwa} / 2019 / 11 / 3 / 92-96$

(C) 2019 DLINE. All Rights Reserved

\section{Introduction}

With the rapid development of computer technology and Internet and the further accelerated the progress of information technology, the wave of informatization impacted on every aspect of human society, updated the increasing information, and leaded the changes of the amount of information. If teachers were not able to learn new knowledge and technology in time, that teachers could be eliminated by the society. Therefore, to master the latest information in time was to adapt to the inevitable requirement of social development on the information processing ability, and also became the ability. Colleges and universities were the important base for talents in our country, it shouldered on the responsibility of cultivating talents that the society needed. In the information age, the teaching content of higher education was abundant, and was also growing breadth and depth. The teaching resources became more and more rich. There was no national boundaries and geographical restrictions in today's education, innovation and teaching model, teachers' knowledge of channel. While facing these information and content, the teachers shall improve their ability of handling the information and accomplishment.

\section{Basic Information of Literatural and Litural Literacy}

Information literacy was often mentioned in modern society, so, what was information literacy? In fact, information literacy was

92 International Journal of Web Applications Volume 11 Number 3 September 2019


a new concept, which was pointed out by American Paul Zurkowski in last century in the mid 70s. Information literacy was the information-processing ability and skills for few tools. While, other scholars of other countries had added some information based on this. Among them, Bruce put forwarder the information literacy should contain the below concept, such as: the idea of the information sources, information process, information technology, knowledge extending, knowledge construction, information control, etc.

And with the further development of society, many generalization and summary had been put forwarder by many experts of information literacy of our country, and the summary of professor An-bang XIE was the most comprehensive and accurate. It has the following several aspects of information literacy of the views and opinions: First, the people should have a correct understanding the characteristics of different information, there was a understand for the desire of the information, and was able to learn computer information technology to the relevant sensitive information. Second, the importance of the work for us was able to correct understanding of the information, and information to be able to solve our problems in study and work to confirm their information needs, and could find all kinds of access to information channels. Third, it shall have keep information moral quality, and take the initiative to safeguard information security.

\section{Status Quo Analysis of Teachers' Information Literacy During Colleges and Universities Teaching Process}

Colleges and universities was the important base of fostering talents in our country, the quality of teachers in colleges and universities for the cultivation of the students had very important influence, and the modern teacher's information literacy, the most important qualities of a informatization reform of the teaching of higher education, which required the participation of all the teachers, it required that teachers in colleges and universities have very high information literacy. At present, our country colleges and universities teachers' information literacy was generally low, even they interpret information literacy for the simple use of information tools, it would not be able to play the function of the information technology to the education teaching, so the colleges and universities must improve teachers' information literacy, and then improved their teaching quality.

Through the investigation and analysis, on the basis of the study of teachers' information literacy current problems, and put forward some measures, detailed descriptions below:

\subsection{To Strengthen College Leadership Values, make the Training Plan}

In order to increase colleges and universities teachers' information literacy, and cultivate teachers' information processing ability, we need to do two aspects. First, to strengthen the leadership, school leadership realized the improvement of teachers' information literacy to the important role of education teaching reform at present stage, at the same time it also determined the level of talent cultivation in colleges and universities, to truly carry out the work and cultivate teachers' information literacy form system. Second, we should establish a scientific and reasonable training plan, and the training scheme formulated as a subject to study. It needed to learn from domestic and foreign many efficient success. More important, it was combined with the actual situation of their universities, and worked out the solution after a review of relevant departments and organizations, so, the colleges and universities have approved. In the process of implementation, the results of the present scheme for acceptance shall be changed timely to be better.

\subsection{Intensify Propaganda, Change Teachers' Ideas}

To enhance the information literacy of teachers in colleges and universities, we had colleges and universities to increase the publicity of information technology, and made full use of the school propaganda techniques and tools to promote information technology function, carried out various forms of information skills exchange activities, especially some about the education teaching, scientific research and learning new knowledge exchanges. Get through these different forms of propaganda and change teachers' ideas, teachers should fully realize, for these emerging technologies, the teacher must have new teaching concept and information skills, and learned through propaganda, further changed teachers' ideas and attitude, let them deeply aware that in the face of emerging information technology, if they did not have new teaching ideas and information skills, teaching effect would not be any change and breakthrough, it could cause very serious to the cultivation of talents to adapt to it or not.

\section{Cultivation Measures for Teachers in Colleges and Universities Information Literacy}

Information literacy goal of teachers in colleges and universities to cultivate goal was that teachers could use the information method and training idea, and then improved their teaching quality. The realization of the information literacy ability mainly

International Journal of Web Applications Volume 11 Number 3 September 2019 
relied on information technology. Below was the method for teachers improving the information literacy. Details see below chart:

\begin{tabular}{|c|c|c|}
\hline \multirow{9}{*}{$\begin{array}{l}\text { The methods to improve } \\
\text { the information literacy of } \\
\text { teachers }\end{array}$} & \multirow{2}{*}{ Education Degree } & $\begin{array}{l}\text { 1. Undergraduate course and specialized subject degree of } \\
\text { self-study and correspondence }\end{array}$ \\
\hline & & $\begin{array}{l}\text { 2.The graduate degree of information technology education and } \\
\text { education technology. }\end{array}$ \\
\hline & \multirow{2}{*}{ Short-time training } & $\begin{array}{l}\text { 1.Short-term training in colleges and universities, research } \\
\text { departments and other organizations. }\end{array}$ \\
\hline & & $\begin{array}{l}\text { 2. To organize the backbone of the teacher training government } \\
\text { organized. }\end{array}$ \\
\hline & \multirow{2}{*}{ Same campus training } & 1. To organize the Information technology training at leisure time. \\
\hline & & $\begin{array}{l}\text { 2. To review the information technology and curriculum integration } \\
\text { teaching. }\end{array}$ \\
\hline & \multirow{3}{*}{ Spontaneous training } & 1. Read the information technology education related magazines. \\
\hline & & $\begin{array}{l}\text { 2. To participate in the network BBS topic discussion, exchange } \\
\text { experience. }\end{array}$ \\
\hline & & 3. Actively participate in various seminars \\
\hline
\end{tabular}

Below was the few method aiming at colleges and universities teachers' information literacy training:

\subsection{Paying Attention to the Information Concept of Teachers Cultivation}

To cultivate information literacy of teachers, it must change their traditional teaching idea, and improve their awareness of information technology and sensitivity. Long-term since, our country's education sector and many education workers did not paid enough attention to this, information literacy had been as a method of evaluation of teachers' teaching quality, and the continuous development of modern information technology. The great changes had taken place in colleges and universities teaching method, many teachers at that time could adapt to the need of modern teaching, of course, there were many teachers lacking basic information knowledge and thinking ability, and the use of modern solutions to improve their teaching quality. So, information technology was developing rapidly, information consciousness, information idea, it was particularly important for teachers to strengthen information literacy training.

\subsection{To strengthen the Information Technology of Training the new Teacher}

It had been a necessary profession skills for every teacher to master the modern methods of teaching, and this quality of this skill directly affected the quality of information literacy of teachers. At present, with the expansion enrollment of colleges and universities, the demand for teachers in colleges and universities increased year by year. If the modern information technology method were added into the pre-service training of teachers, This effectively improved teachers' information literacy.

\subsection{Enhancing the Continuing Education work in Colleges and Universities Teachers' Information Literacy}

During the training of information literacy for teachers in colleges and universities, it was needed to strengthen the continuing education of teachers' information literacy, and take the examine to check the results of the training. It also needed to arrange the backbone of teachers in colleges and universities to had a short-time training in the higher qualified colleges and universities. The school also can use holiday or weekends to train teachers for more professional skills. In addition, it also required teachers to cultivate the skills and knowledge of information though the Internet, and reading, to enhance their information literacy.

\subsection{Establishing the Scientific and Reasonable Evaluation System}

Institutions of higher learning in the information technology environment had the direct impact on the important condition of

94 International Journal of Web Applications Volume 11 Number 3 September 2019


training teachers' information literacy level, further strengthened the efforts to teach information literacy training and inspired them to autonomous learning, then improved their information literacy, which was the most direct way. And it was more important to evaluate a teacher's information literacy. It was more stringent to make the evaluation system of requirements, and established the evaluation system, started from the definition of information literacy, set different standards for different levels of personnel. Usually, this evaluation system was divided into two kinds: the teachers' evaluation scale and professional assessment scale.

\subsection{Setting up the Corresponding Incentive Mechanism}

To train the teachers in colleges and universities for information literacy should also be supported by school leaders, and teachers and school leaders should encourage the application of information technology in the teaching process, and should also support new experiment teaching methods for teachers to provide enough time and the necessary funds. The most important thing was that colleges and universities should establish a reasonable incentive mechanism, and improved the enthusiasm of teachers in this respect. We should use modern information technology in the process of teaching teachers shall be rewarded. To master the new information network technology could also carry out some of the information course, excellent course appraisal, etc., improved teachers' information literacy.

\subsection{Forming a Good Information Literacy Training Team}

In colleges and universities teachers' information literacy training in our country started relatively late, various aspects had not done enough to make it perfect, service teachers' information literacy in colleges and universities generally was not high, and the continuous development of society and technology, the teaching work was more and more high to the requirement of teachers' information literacy. And the formation of a high quality team of information literacy training was a very good measures. The local education authorities set up a professional training institution, then set some powerful institutions of further learning to set up an information technology education training center, often of various colleges and universities teachers' information technology training. Institutions should employ excellent teachers for the information technology curriculum guidance, and ensured the quality of classroom teaching and teachers' learning.

\section{Conclusion}

To sum up, realizing information management of the education teaching was an important method to realize the modernization of education, and was also a major forces for promoting the development of the institutions of higher learning forward. In the information explosion today, the process of informatization was very important to the development of institutions in the future. In recent years, colleges and universities in our country informationization had rapid progressed, the result was more significant in infrastructure construction, information system construction, resource development and integration. The core issue in the development of institutions was the teaching quality of school, and the informationization development of teaching. The teacher was the most important factors that affect the quality of teaching, as in colleges and universities informationization environment, teachers' information literacy could directly affect the teaching quality of a school. Therefore, colleges and universities shall take the improvement of teachers' information literacy as the key of the education teaching work.

\section{References}

[1] Xu, Mei-lin. (2009). Research and thinking of Shanghai university teachers' knowledge of modern education technology, Journal of East China Normal University.

[2] Zhang, Qing-wei. (2010). Information literacy and information literacy education, E-education Research, 2010 (2).

[3] Yang, Xiao-guang., CHEN, Wen-yong. (2010). Information literacy and people with information literacy, China Information Review.

[4] Wu, Lan. (2011). The knowledge economy era and the teachers' information lieracy, E-education Research, 2011 (1).

[5] Grafstein, Ann. (2002). A Discipline-based Approach to Information Literacy, Journal of Librarianship, 2002 (04).

[6] Nan, Guo-nong. (2010). The necessary solution of education modernization, Assay collection of Nanguo agricultural electricity education, Higher Education Press.

[7] Zhou, Bing-feng. (2010). Research and Practice on training model of higher university education technology in beijing city, Modern Education Technology, 2010 (9). 
[8] Dunn, K. (2002). Assessing Information Literacy Skills in the California State University: A Progress Report, Journal of Academic Librarianship, 2002, (01) 26-35. doi:10.1016/S0099-1333(01)00281-6.

[9] DUAN, Bao-xia. (2009). Cultivation and improvements the strategy of university teachers' information literacy, Forum Contemporary Education, 2009 (12).

[10] BU, Zhong-fei., WEI, Kai. (2009). Strategy on improving teachers' information literacy under digital campus environment, China Audio-visual Education, 2009 (11).

[11] GE, Xiang-guo., BAO, Ming-yong. (2012). Information literacy and cultivation for higher vocational college teachers, Science \& Technology Information, 2012 (4) Journal of Xi'an University of Arts \& Science (Natural Science Edition)

[12] Information Skills in Higher Education: a SCONUL Position Paper [EB/OL]. http://scounl.ac.uk.

[13] Kranich, Nancy. (2005). Libraries and the information commons:a discussion paper. http.ala.org/ala/washoff/oitp/icprins.pdf. 